\author{
تغييرات شكلهاى يتاسيم و كانىهاى رسى در خاك زير كثت يرتقال \\ با سنين مختلف در شهرستان داراب (استان فارس) \\ وجيهه شاهرخ، حسين خادمى " و حسين شريعتمدارى' \\ (تاريخ دريافت: 1\%99/T/19؛ تاريخ يذيرش:
}

جكيده

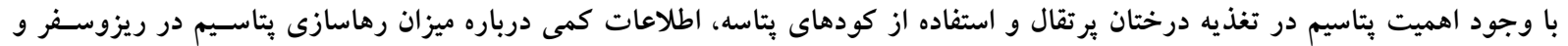

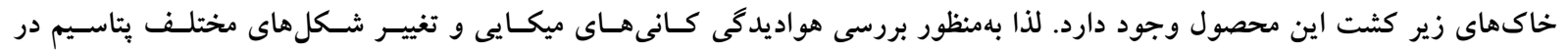

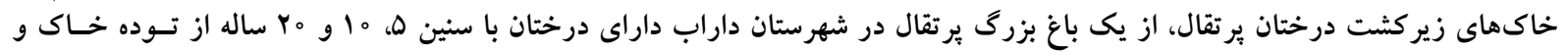

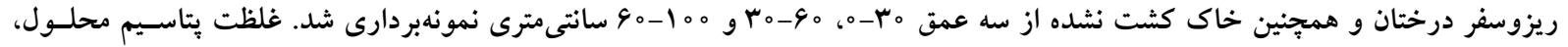

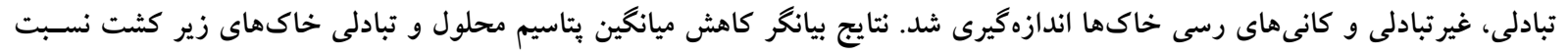

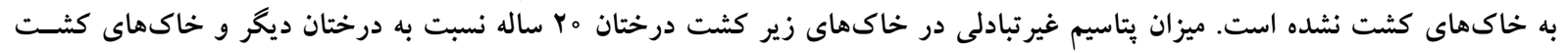

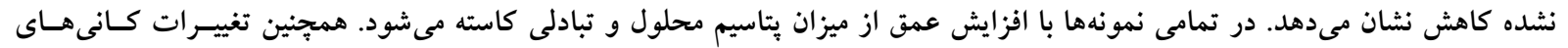

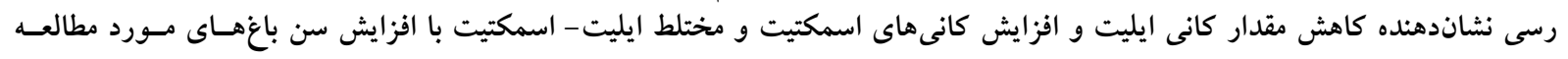

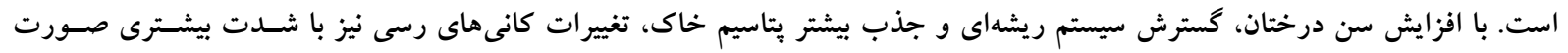

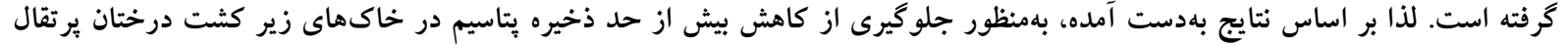

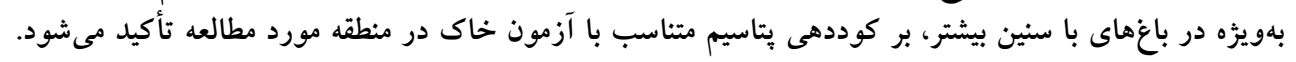

وازههاى كليدى: بِتاسيم، ريزوسفر، كانىهاى رسى، برتقال

1 ا. كروه خاكشناسى، دانشكده كشاورزى، دانشكاه صنعتى اصفهان، اصفهان

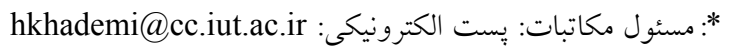


يتاسيم خاك در يك دوره TM ساله در اكوسيستم كاج را كـزارش

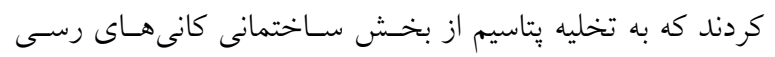

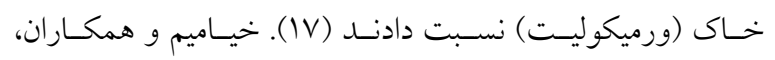

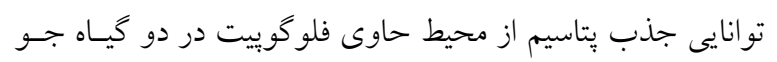

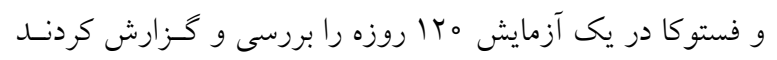

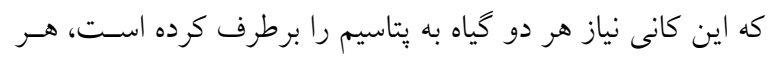

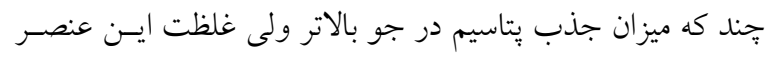

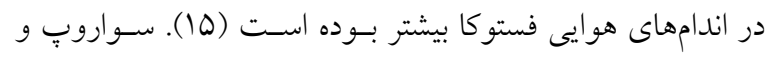

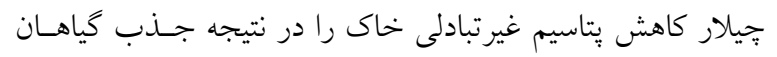

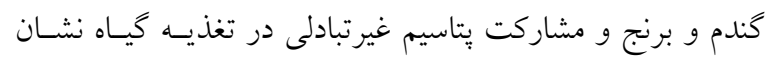

دادند (Y) (ب).

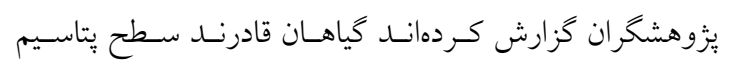

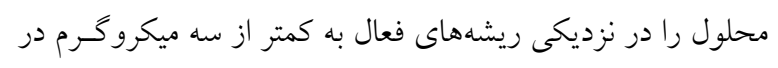

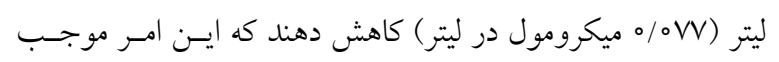

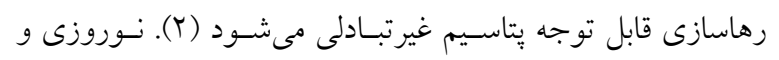

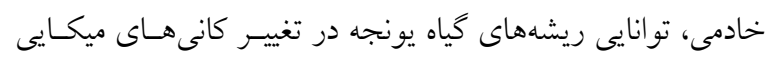

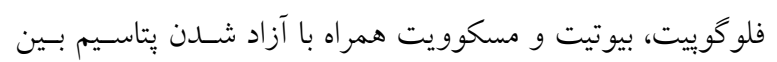

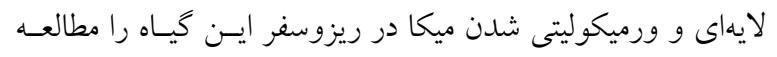

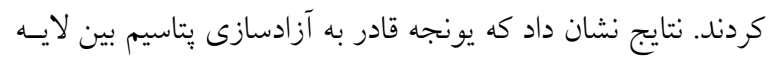
اى از فلوكوييت و بيوتيت در طول دوره كشت بوده و يتاسيم آزاد

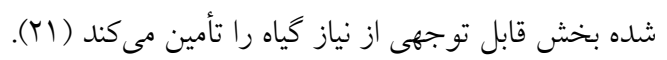

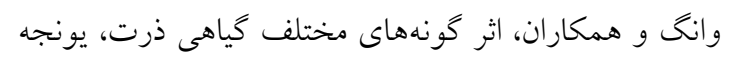

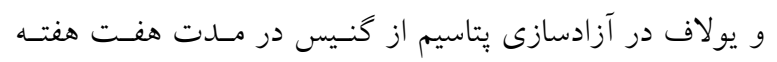

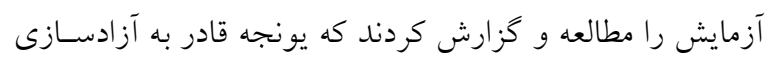

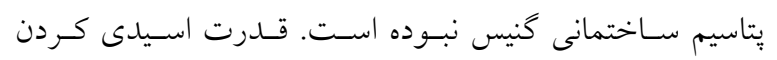

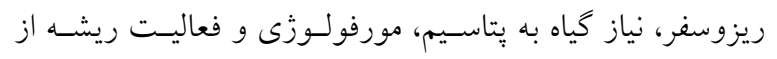

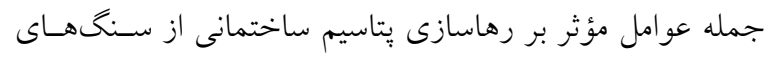

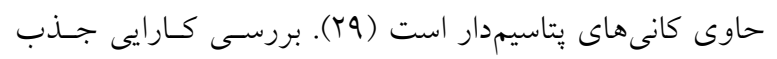

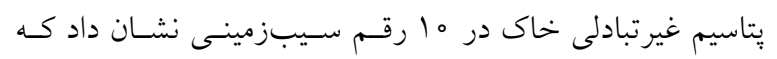

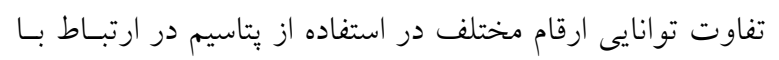

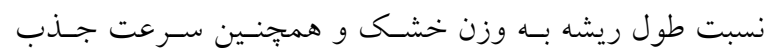
يتاسيم در واحد طول ريشه است (YV)
مقدمه

ريشههاى گياهان بهعنوان اندام اصلى براى جذب عناصـر غـذايى

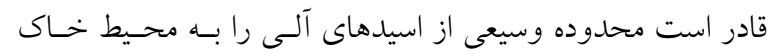
اطراف خود آزاد كند. حضور اين تركيبات و جمعيست ميكروبسى، قابليت اسـتفاده عناصـر غـذايى و حلاليـت عناصـر تغذيسهاى در ريزوسفر را تحت تأثير قــرار داده و تغيــرات حاصسله گيـاه را در مقابله با شرايط شيميايى سخت يارى مىدهند (11). يزوهشها نشان مىدهند كياهان بـهدليل داشـتن ترشسحات

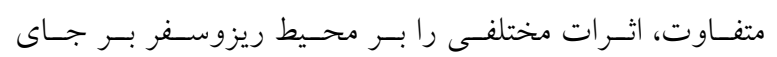
مى گذارند. ريزوسفر كياهان با اثرات ويزه خود باعث رهاسازى يتاسيم از كانىهاى خاى شده و در ايسن رابطـه تغييـر و تبـديل

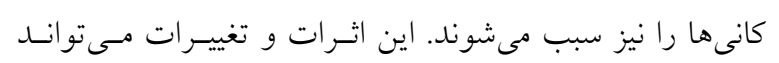

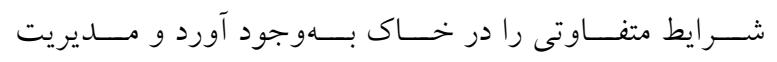
حاصلخيزى بهويزه در مورد عنصر يتاسيم را تحست تـأثير قـرار

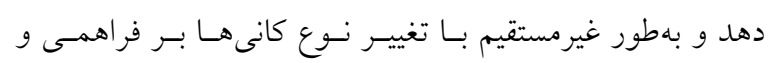
جـذب سـاير عناصـر غـذايى نيـز اثـر بخـذارد (11). شـادى و همكاران تأثير اسيدهاى آلى در رهاسازى يتاسيم را بـهـ تشـكيل

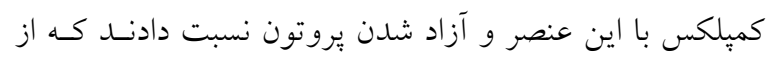
اين طريق باعث تسهيل هواديدكى كانىها مىشود (YT). يتاسيم يكى از عناصر اصلى مورد نياز گياه است و به جهـار شكل كلى محلول، تبادلى، غيرتبادلى و سـاختارى در خـاكهـا وجود دارد (Uه). جذب يتاسيم توسط گيـاه بـا غلظـت يتاسـيم محلول همبستخى نشان مىدهد كه اين غلظت نيز تحت كنتسرل روابط تعادلى بين يتاسيم محلول، تبادلى و يتاسيم سـاختارى در

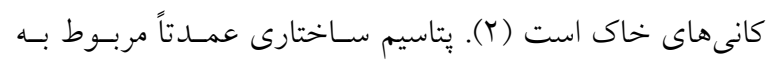

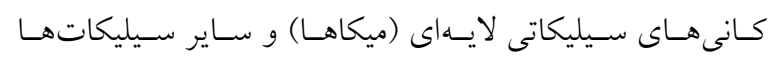

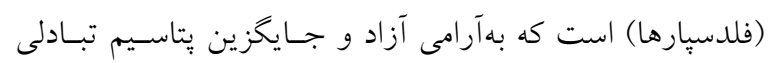
شده و در طول فصل رشد در اختيار گياه قـرار مسى گيـرد (11). مطالعات زيادى نشان دادهاند كـهـ آزادسـازى بتاسـيم از ذخـاير غيرتبادلى يا ساختمانى مسى توانـــ بـهـور معنسى دارى در ميـزان يتاسيم جذب شده توسط گياه نقش داشته باشد (YM). ماركويتز و ريختر تغييرات قابل توجهى در شكلهاى مختلف 
ايران در اختيار است. لـذا هـــف از ايـن يـزّوهش مطالعـه اثـر

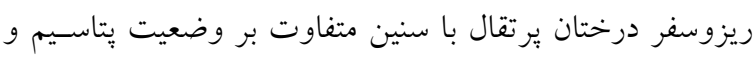
كانىشناسى رسى خاك در منطقه داراب استان فارس است.

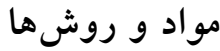

مطالعه مورد نظر در برخى باغهاى برتقـال واقـع در شهرسـتان

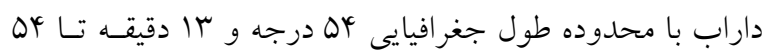

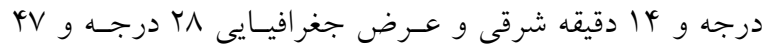

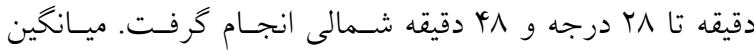

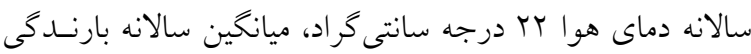

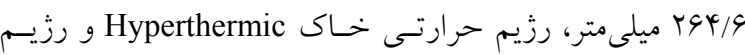
رطوبتى خاك Tempustic است. اين مطالعه بهصورت آزمايش فاكتوريل در قالب طرح كاملاً

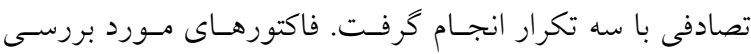

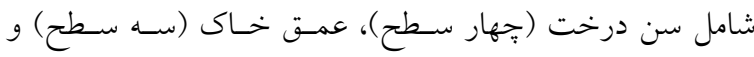

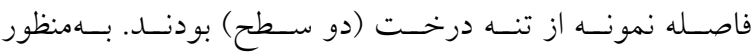

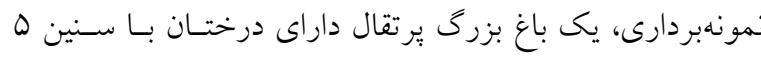

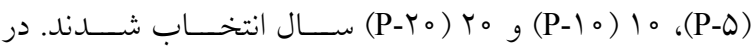
مجاورت باغ مورد مطالعه، قطعه زمينى بكـر و دسـت نخـورده بـهنعنوان شـاهد انتخـاب شـــ مــاده مـادرى، اقلـيم و عمليـات مديريتى در باغهاى مورد نظر را مىتوان كم و بيش يكسـان در

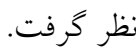
در فواصل افقى مجاور تنه (به فاصله مr- صفر سانتىمترى از تنه درخت بهعنوان ريزوسفر ا R) و بخش بايانى سايهانــاز

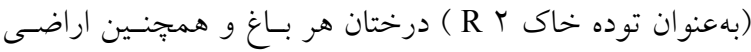

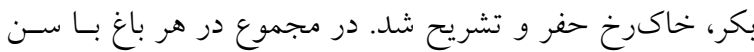

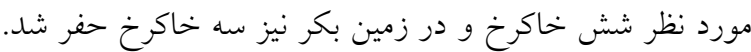

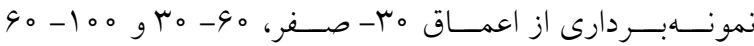

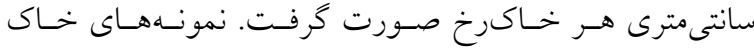

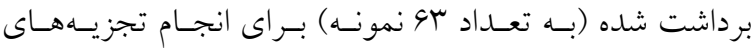

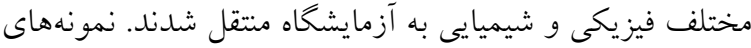

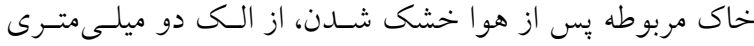

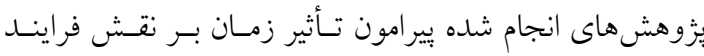

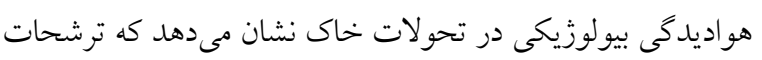

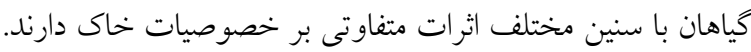

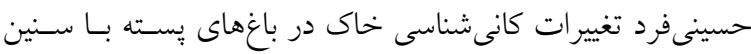

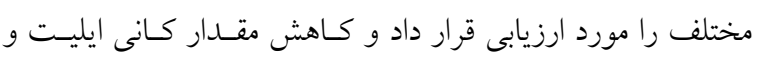

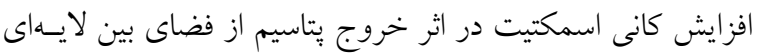

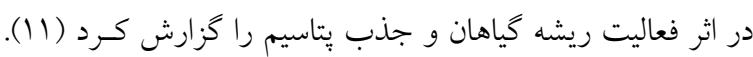

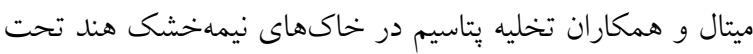

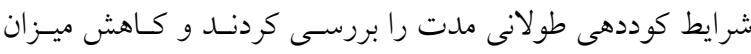

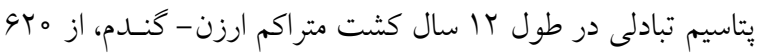

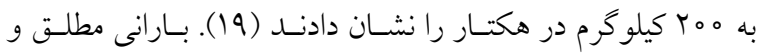

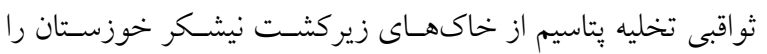

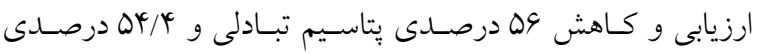

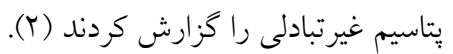
بر اساس آمار ارائه شده توسط سازمان جهـاد كشـاورزى استـان

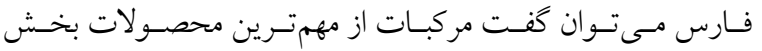
كثاورزى و باغبانى در اين استان بوده و بنـابراين بررسى اثتر ايسن كياهان بر تحولات و تكامل خاك منطقه از اهميت بسز ايى برخوردار

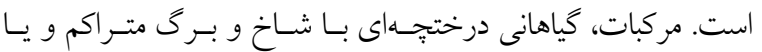

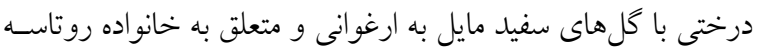
(Rutaceae)

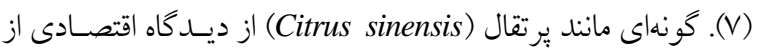

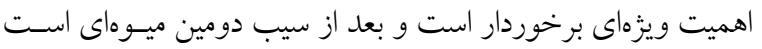
كه در جهان مورد مصرف عموم مردم است (1)). حداكثر بازدهى فرايند توليد محصولات با كيفيت مطلـوب، بدون درك و دانش كافى درباره خاك و مواد غذايى مـورد نيساز درختان بارور امكانيذير نيست. با وجود مصرف رايج كودهـاى

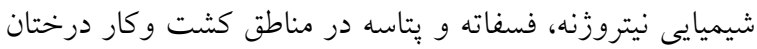
يرتقال در ايران، اطلاعات كمى درمورد وضعيت عناصر خـاك، نياز غذايى كياه و توصيه كودى دقيق در دسـت اسـت. در ايسن

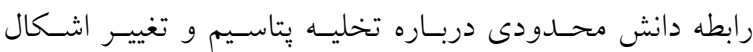
مختلف اين عنصر غذايى در خاكهاى زير كشـت مركبـات در 
نشر يه علوم آب و خاك (علوم و فنون كشاورزى و منابع طبيعى) / سال بيست و سه / شماره دوم / تابستان لهه|

\begin{tabular}{|c|c|c|c|c|c|c|c|c|c|c|c|c|}
\hline \multicolumn{13}{|c|}{ جدول ا. ميانخين ويزگى هاى فيزيكى و شيميايى خاكهاى ريزوسفرى مورد مطالعه } \\
\hline \multicolumn{3}{|c|}{ شاهد } & \multicolumn{3}{|c|}{ PYo } & \multicolumn{3}{|c|}{$\mathrm{P} \backslash 。$} & \multicolumn{3}{|c|}{$\mathrm{PQ}$} & \multirow{2}{*}{ 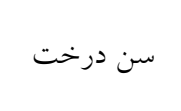 } \\
\hline \multicolumn{3}{|c|}{ عمق خاى (cm) } & \multicolumn{3}{|c|}{ عمق خاى (cm) } & \multicolumn{3}{|c|}{ عمق خاى (cm) } & \multicolumn{3}{|c|}{ عمق خاى (cm) } & \\
\hline$\frac{0}{1}$ & $\begin{array}{l}0 \\
\hat{a} \\
\vdots \\
i\end{array}$ & $\frac{0}{1}$ & $\frac{0}{1}$ & $\begin{array}{l}0 \\
\hat{a} \\
\vdots \\
i\end{array}$ & $\frac{0}{1}$ & $\frac{0}{1}$ & $\begin{array}{l}0 \\
a \\
\vdots \\
i\end{array}$ & $\frac{0}{1}$ & $\frac{0}{1}$ & $\begin{array}{l}0 \\
\hat{a} \\
\vdots \\
i\end{array}$ & $\frac{0}{1}$ & خصوصيات \\
\hline$\circ / V Y$ & $\circ / V$ & $0 / 94$ & .01 & $0 / T^{4}$ & .09 & 每 & - & $\circ / 0$ & $0 / Y \Lambda$ & $0 / Y q$ & $0 / \mu_{4}$ & Ece $\left(\mathrm{dS} \mathrm{m}^{-1}\right)$ \\
\hline$N / \circ 9$ & $N / \circ q$ & V/99 & $1 / \mu^{4}$ & $N / \circ q$ & V/AG & $\Lambda / 01$ & $N /{ }^{4}$ & $V / 90$ & $1 / 19$ & $N / 1$ & $1 / 09$ & $\mathrm{pH}$ \\
\hline ./Qr & $0 / 94$ & $1 / 1 \wedge$ & .199 & $\circ / \mathrm{VI}$ & $1 / \pi r$ & $0 / 9 \mathrm{~V}$ & $0 / 91$ & 1 & $\circ / \mathrm{VI}$ & $\circ / 19$ & 1/1/ & $\mathrm{OM}(\%)$ \\
\hline$\Delta \Delta$ & $\Delta F / q$ & $\Delta r / \Lambda$ & $\Delta T / T$ & $\Delta \circ / \Lambda$ & $01 / 1$ & $\Delta T / 1$ & $0 \circ / \Delta$ & $49 / 0$ & $0 \circ / 4$ & $0 \circ / 1$ & $0 \circ / 9$ & آهك معادل (.) \\
\hline $10 / \pi$ & IV & $1 N / 0$ & $1 / /{ }^{\prime}$ & IN/Ar & $\mid N / 4$ & $r I / 9 T$ & $Y \Psi / l$ & $T Y / T$ & $r \circ / V$ & $r \mu / V$ & $T r / D$ & رس (.) \\
\hline$Y T / T$ & $F Y / q$ & ky & $\varphi Q / \mu$ & $y+/ \Lambda$ & $41 / 9$ & KT/Y & $r q / r$ & rV/G & $r V / l$ & $\varphi \circ / 9$ & $\mu r / D$ & سيلت (.) \\
\hline$Y Y / 9$ & $\varphi_{0} / l$ & $\mathrm{rV} / \mathrm{d}$ & $r q / 4$ & $r 4 / r$ & $r q / v$ & $r \Delta / V$ & re/9 & rN/l & $Y T / T$ & $r \Delta / v$ & ry & شن (\%) \\
\hline لو لوم & لو لوم & لوم & لوم & لوم & لو لوم & لوم & لوم & لوم & لوم & لوم & لوم & 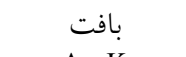 \\
\hline$r v r$ & $9 T_{1}$ & FAV & 19. & rmq & qVo & 109 & $r \circ q$ & TVI & 194 & 191 & TAY & $\begin{array}{c}\mathrm{Av}-\mathrm{K} \\
\left(\mathrm{mg} \mathrm{kg}^{-1}\right)\end{array}$ \\
\hline reD & $r \circ q$ & ros & $1 M$ & aro & (4) & lov & roq & TEY & 194 & 109 & rVT & $\begin{array}{c}\mathrm{Ex}-\mathrm{K} \\
\left(\mathrm{mg} \mathrm{kg}^{-1}\right)\end{array}$ \\
\hline $\mathrm{V} / \mathrm{A}$ & $1 T / 0$ & rI & T/A & $r / 9$ & MT & $1 / \Lambda$ & $T / q$ & $\Lambda / \mathrm{V}$ & r & $r / \circ V$ & $9 / \pi$ & $\begin{array}{c}\text { So-K } \\
\left(\mathrm{mg} \mathrm{kg}^{-1}\right)\end{array}$ \\
\hline $4 \vee 19$ & $\forall Q \circ \wedge$ & F्वाT & rary & HYQS & هו" & 4) $19 V$ & 4190 & $\varphi \circ r v$ & ra90 & $4 \circ 40$ & Yिo。 & $\begin{array}{c}\text { Nex-K } \\
\left(\mathrm{mg} \mathrm{kg}^{-1}\right)\end{array}$ \\
\hline
\end{tabular}

شــده و تحست تيمارهـاى اشـباعسـازى بــا كلـرور منيزيـوم، اشباعسازى با كلرور يُّاسيم، اعمال تيمار بخــار اتـيلن گليكـول روى نمونههاى اشباع شده از منيزيوم و تيمار حرارتى در دمساى •Dه درجه سانتى گ اد روى نمونهاى اشباع شده با يتاسيم قرار كرفتند (9). نمونه هاى تيمار شده با يراشسنج يرتو ايكس مـدل در محدوده زاويهاى ب تا مب درجه (Bruker AXS , USA) D8

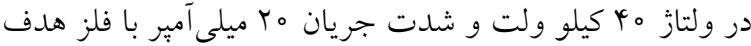
مس در آزمايشــاه مركـزى دانشـحاه بِلى تكنيـك كارتاخنـا در

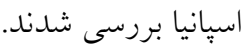

\section{نتايج و بحث}

ويزّحى هاى فيزيكى و شيميايى خاى

ميانخين برخهى ويزخى هــاى فيزيكى و شـيميايى خـاكهـاى

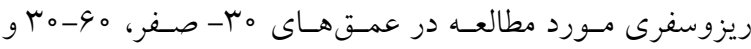

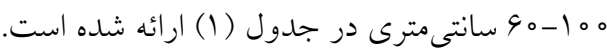
مقادير رس، سيلت و شن خاكها بهترتيب در محسدوده هـ
عبور داده شدند. ويزخى هاى فيزيكوشيميايى خاك شامل توزيـع

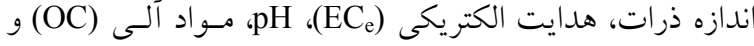
كربنات كلسيم معادل (CCE) با استفاده از روشهاى اسـتاندارد اندازهگيرى شد (YN). شكل هاى مختلف يتاسـيم شـامل پِتاسـيم محلـول (So-K)، تبـادلى (Ex-K) (قابـل اسـتخراج بـا اسـتات آمونيوم نرمال و خنتى)، قابـل جـــب (Av-K) و قابـل عصـاره

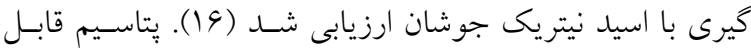
جذب از مجموع يتاسيم محلول و يتاسيم تبادلى بهدسـت آمـد. يتاسيم غيرتبـادلى (Nex-K) بـر اسـاس اخـتلاف يتاسـيم قابـل

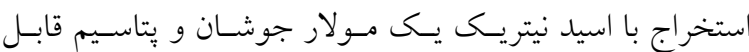

$$
\text { استخراج با استات آمونيوم محاسبه شد. }
$$

براى بررسى كانىهاى رسى خاك، از بـافر اسـيد اسـيكى و استات سديم با بِ هاش ينج، آب مقطر، آب اكسيزنه هب درصد و تيمار سيترات- بى كربنات- دىتيونات بهترتيب بـراى حـذف كربناتها و نمكهاى محلول، گَج، مواد آلى و اكسيدهاى آهـن استفاده شد (ץ). پِ از آمادهسـازى اوليسه، ذرات رس تفكيـك 


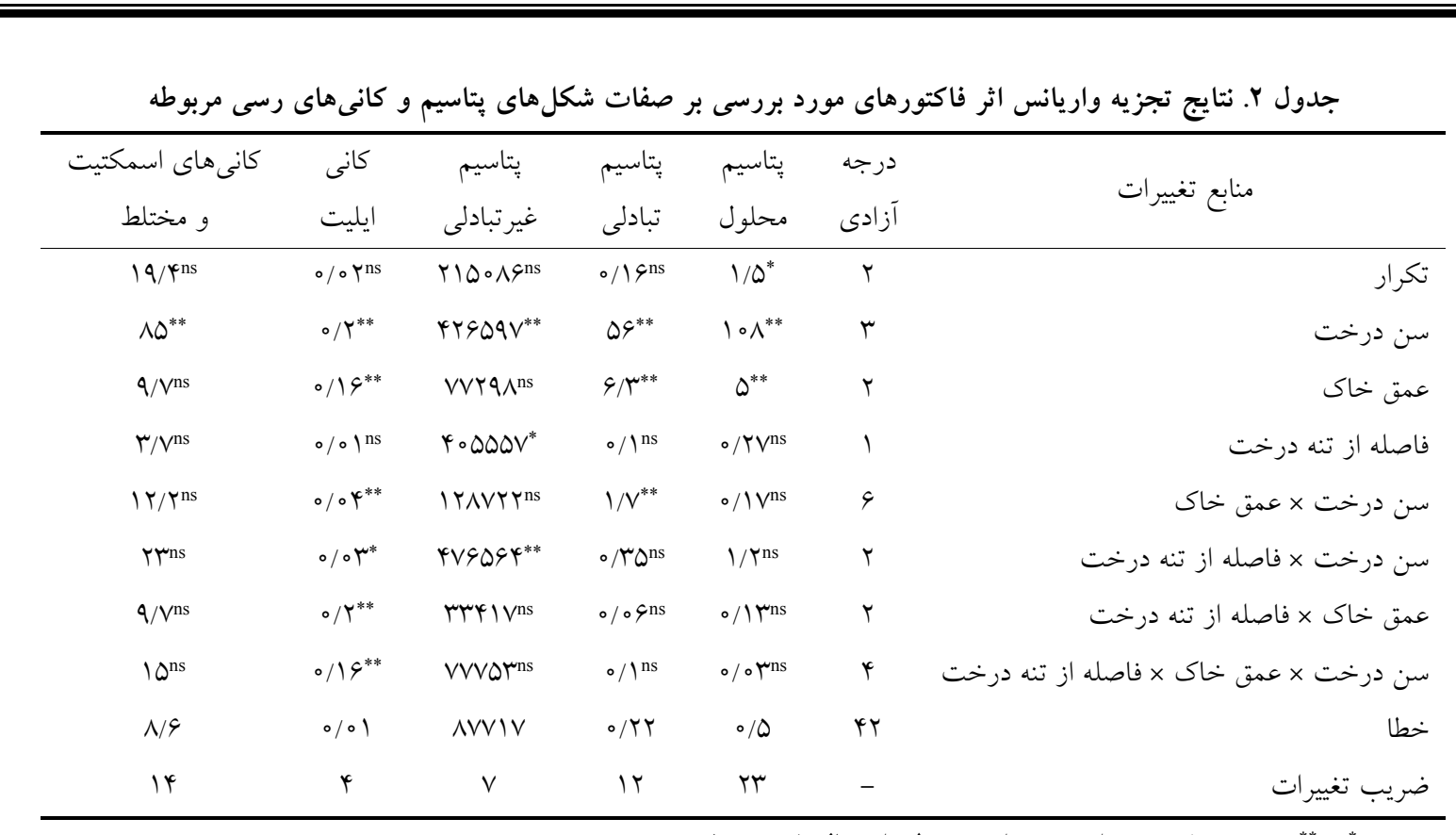

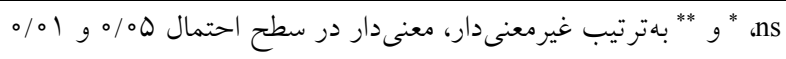

در سطح يك درصد معنىدار هستند. بررسىها گوياى اين است كه اثر متقابل بين سن درخت و فاصله از تنه درخت بر صـفات يتاسيم غير تبادلى و كانى ايليت و اثر متقابل بين عمـق خـاك و فاصله از تنه درخت و همجينين اثرات متقابل بين سـن درخــت، عمق خاى و فاصله از تنه درخت تنها براى صفت كانى ايليـت معنى دار هستند و بنابراين صفات ديخر بسهور معنسىدار تحست تأثير اين اثرات متقابل قرار نخرفتند.

\section{يتاسيم محلول}

بتاسيم محلول در خاك زير كشت درختان با سنين متفـاوت در محدوده 1/1 تا צr ميلى گرم بر كيلـو گرم قـرار دارد. خاكهـاى كشت نشده بيشترين ميانگين بتاسيم محلول در خاك و درخـت

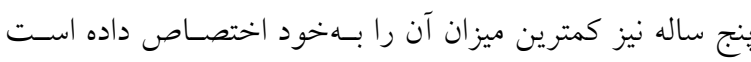

آزمون مقايسه ميانكين ها نشان داد كـهـ در عمـق هـ- صـفر

سانتى مترى خاى ريزوسفرى، مقدار يتاسيم محلول نمونسههـاى مورد مطالعه بهصورت خاك كشت نشده > درخت مب سـاله > درخت ه ساله > درخت ه ا ساله است. ميـزان كـاهش بيتاسـيم درخت مب ساله نسبت به زمين باير در سطح بنج درصد تفاوت

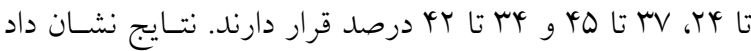
كه خاكهاى مورد مطالعه داراى مقدار زيادى آهـك، سـاختمان مكعبى كوشهدار و بافت لومى هستند. ميانخين ماده آلى خـاك

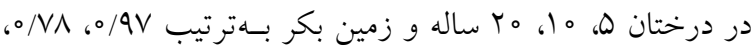
o/AV و و د/VA درصد بهدست آمد كه بيشترين ميـزان آن در افـق سطحى مشاهده مىشود و با افزايش عمـق از مقــدار آن كاسـته مىشود. هدايت الكتريكى در خاكهاى مورد بررسى بسيار كـم بوده و در خاك درختان ه و هب ساله بهترتيب داراى كمترين و بيشترين مقدار اسـت. ارزيـابى بِهــاش در خـاك زيـر كشـت درختان يرتقال نشان داد كه با افـزايش عمـق خـاك، ميـزان آن افزايش مى يابدكـه مسى تـوان علـت را بـهـ كـاهش مـواد آلى و ترشحات ريشه در اعماق بايينتر نسبت داد.

نتايج تجزيه واريانس جدول (Y) نشان مىدهـد كـه فـاكتور سن درخت براى تمامى صفات مورد بررسى، عمق خاى بـراى همه صفات بـه جـز صـفات يتاسـيم غيـر تبـادلى و كانىهـاى اسـمكتيت و مخـتلط در سـطح يـك درصسـ معنسى دار هسـتند درحالى كه در فاكتور فاصله از تنه درخت تنها در مورد يتاسـيم غيرتبادلى معنسى دارى مشــاهده مى شـود. اثـر متقابـل بــين سـن درخت و عمق خاك براى صفات بتاسيم تبادلى و كـانى ايليـت 


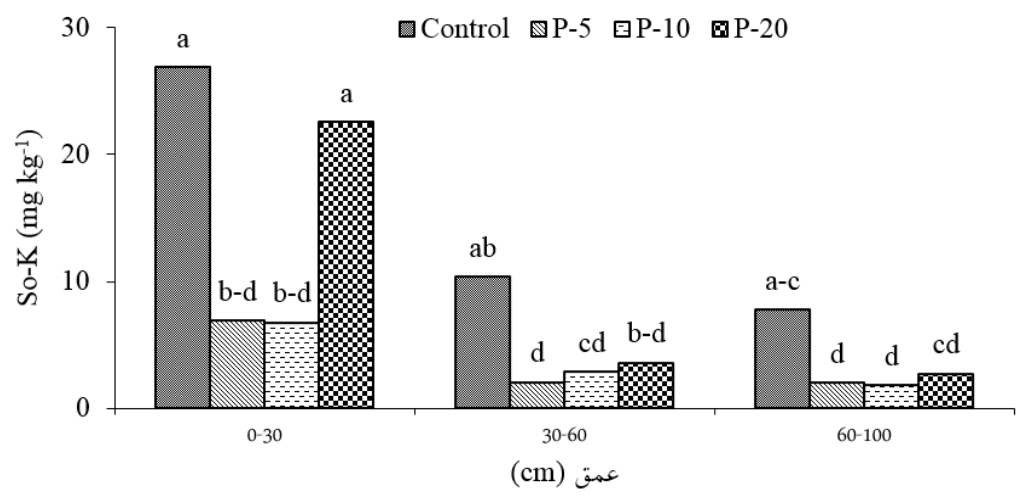

شكل ا. اثر سن درختان يرتقال بر بتاسيم محلول خاك در اعماق مختلف. ميانگينهاى داراى حروف مشتر فاقد تفاوت معنى دار در سطح بنج درصد آمارى هستند.

ريشه در اعماق بايين خاك و جذب بالاتر يتاسيم و تخليـه ايسن

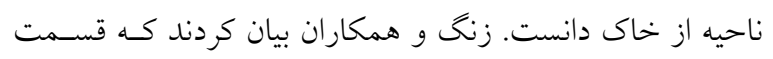

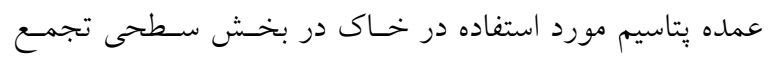

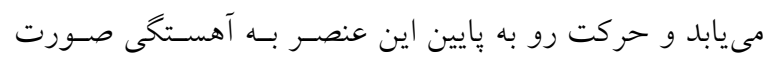

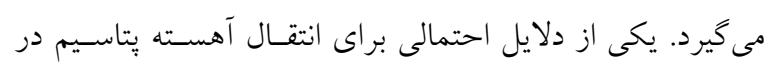

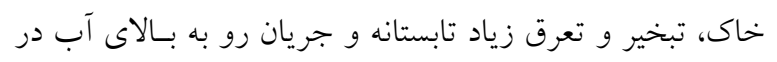

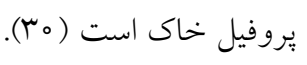

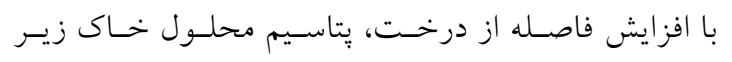

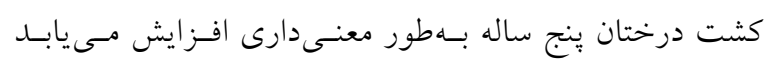

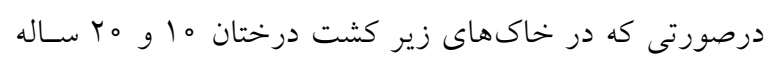

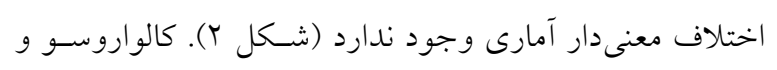

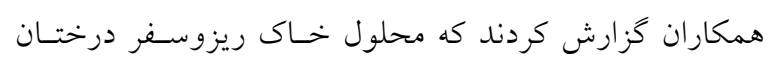

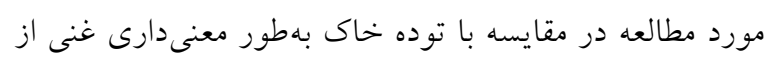

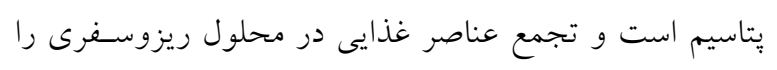

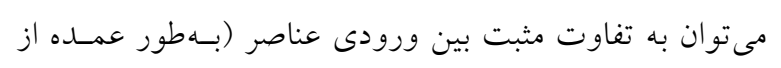

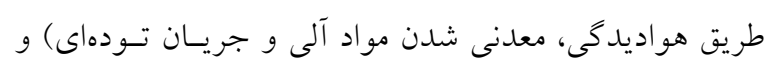

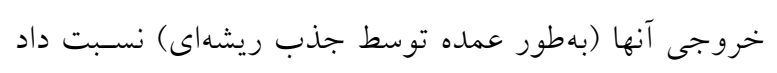

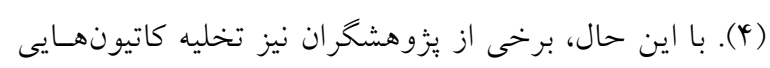

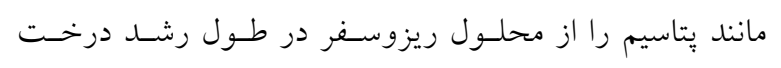

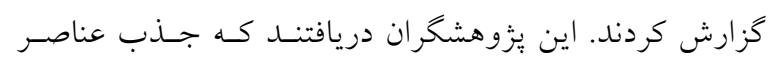

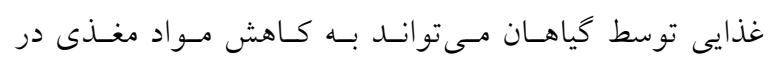
ريزوسفر منجر شود (1 و ه).
معنى دار آمارى نداشت درحالى كه درختان هو و 1 ساله اخـتلاف

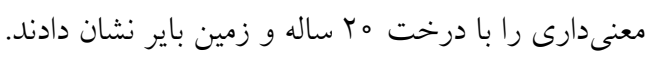

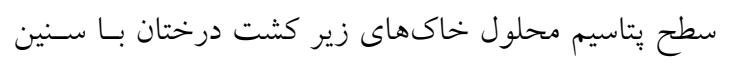

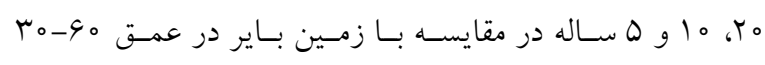

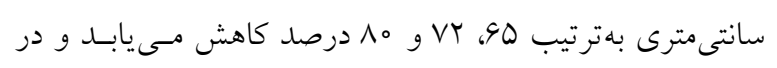

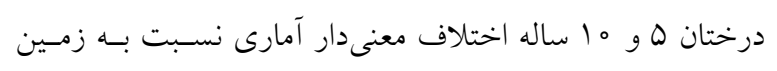

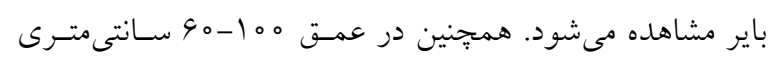

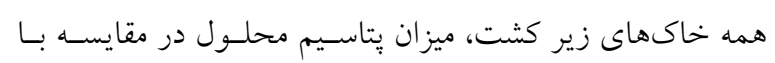

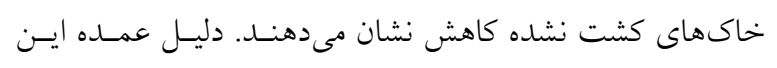

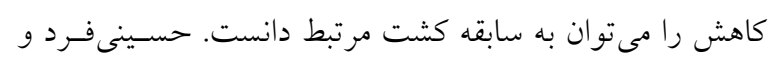

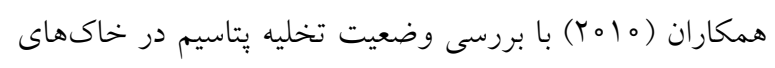

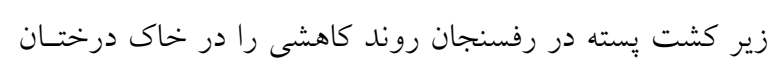
نسبت به زمين باير نشان دادند (Y) (I).

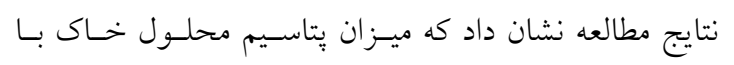

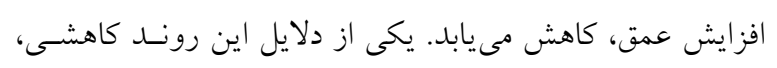

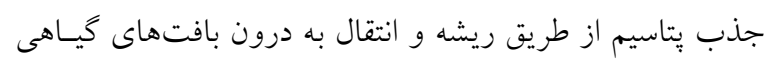

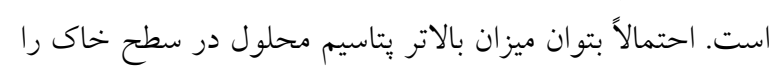

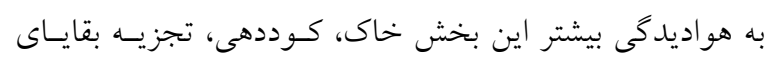

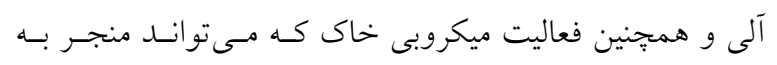

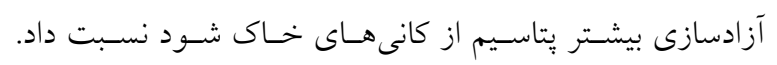

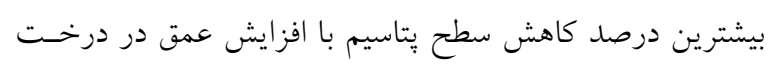

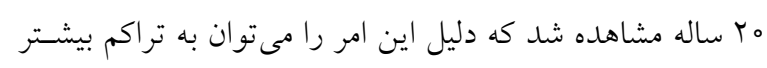




\section{$\square \mathrm{R} 1 \mathbb{\mathrm { R }} 2$}

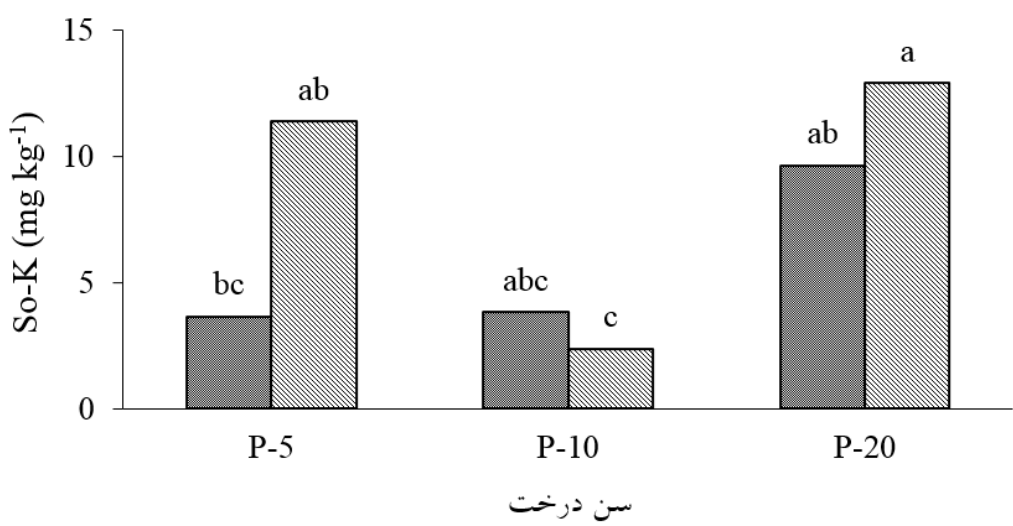

شكل r. اثر فاصله از درخت بر بتاسيم محلول خاكهاى زير كشت درختان برتقال با سنين متفاوت. ميانخينهاى داراى حروف مشترى فاقد تفاوت معنى دار در سطح ينج درصد آمارى هستند. R1 و R2 بهترتيب ريزوسفر و توده خاك هستند.

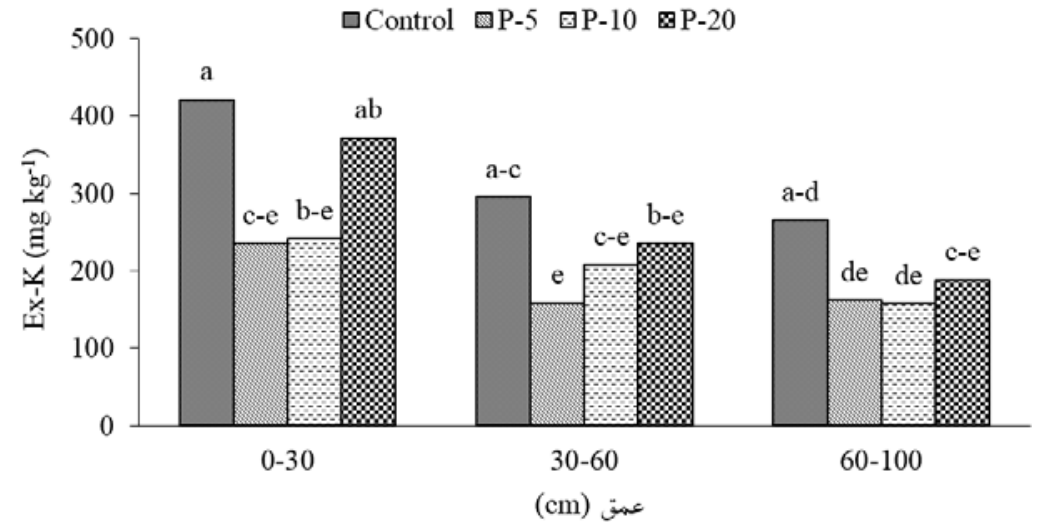

شكل r. اثر سن درختان ير تقال بر يتاسيم تبادلى خاى در اعماق مختلف. ميانگينهاى داراى حروف مشترك فاقد تفاوت معنى دار در سطح ينج درصد آمارى هستند.

تبادلى كاهش يافته است. در همه عمقها نيز بين تيمارهاى سن

درخت تفاوت معنسى دار از نظـر ختاسـيم تبـادلى وجــود نــدارد.

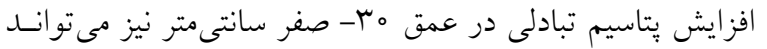
مربوط به فعاليت ريشه و همجنين تجزيه بقاياى گياهى باشد كه منجر به افزايش حلاليـت يتاسـيم و در نتيجسه افـزايش يتاسـيم تبادلى مىشود. الكوى تغييرات يتاسيم تبادلى بين تيمارها تا حد زيادى مشابه تغييرات يتاسيم محلول است. مطالعه خاكهـاى زيركثـت نيشـكر در خوزسـتان توسـط بارانى مطلق و ثواقبى فيروز آبـادى، كـاهش

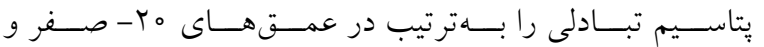

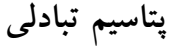
ميانخين مقادير پِتاسيم تبادلى خاكهاى مـورد مطالعـه، هN1 تـا VTV ميلى گرم بر كيلو گرم است كه بيشترين و كمترين ميزان آن بهترتيب مربوط به خاك كشت نشده و درخت ينج ساله اسـت. عدم كشت و كار و برداشت يتاسيم خاك توسط گياه مسىتوانسد يكى از دلايل افزايش ميزان اين عنصر در زمين باير در مقايسـه با خاكهاى زير كشت باشد. نتايج بيانگر كاهش سطح يتاسيم تبادلى خاكهاى زير كشت در همه عمقها نسبت به خاى كشـت نشــده اسـت (شـكل ب). همجنين به نظر مىرسد با افزايش عمق در همه خاكها يتاسـيم 

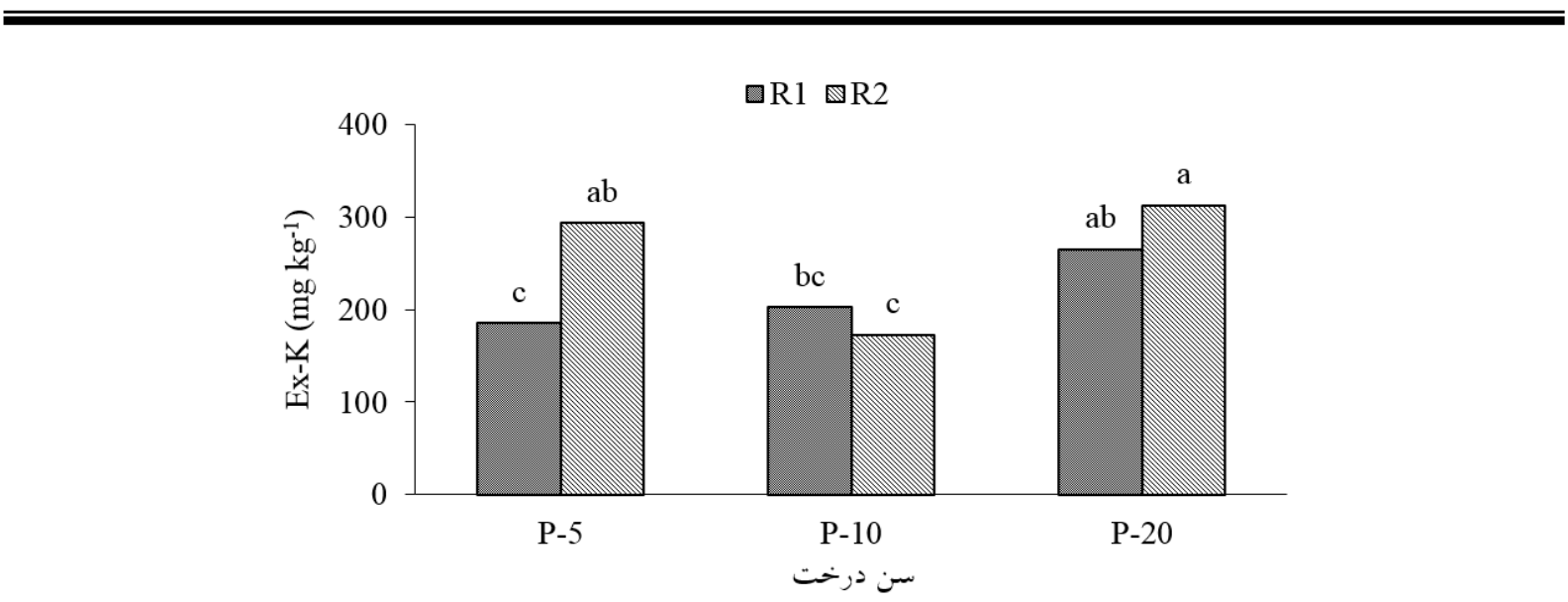

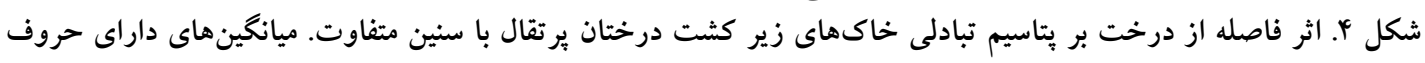

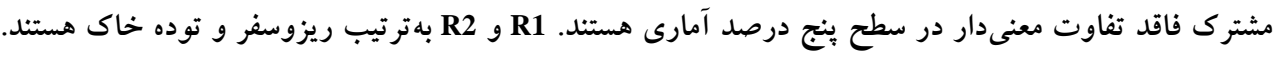

معنى دار آمارى در سطح ينج درصد متعلق به درخت يـنج سـاله

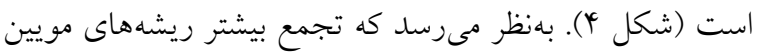

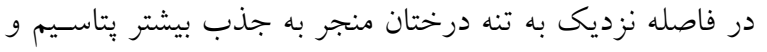

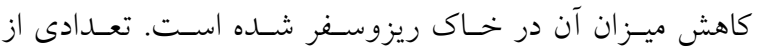
يُزوهشكران نيز غنى بودن خاك ريزوسـفر از يتاسـيم تبـادلى را

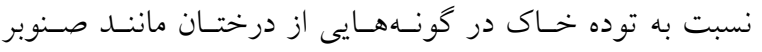

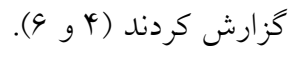

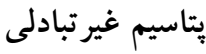

ميانخين مقادير يتاسـيم غيرتبـادلى خاكهــاى مـورد مطالعـه از

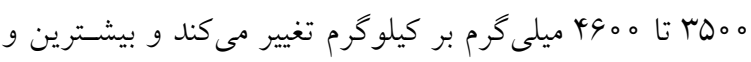

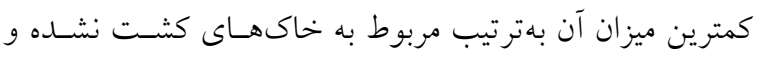

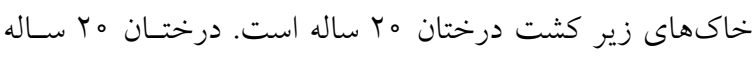
در طى سالهاى متمادى بهعلت نياز بيشتر به يتاسيم در مقايسـه

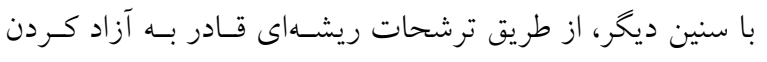

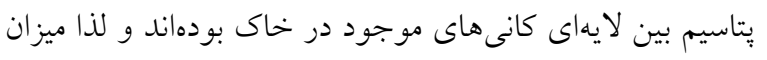

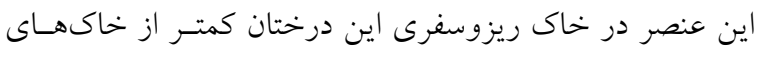

$$
\text { زير كشت ساير سنين است. }
$$

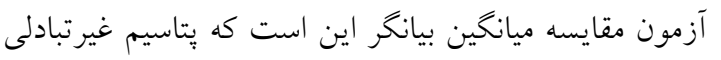

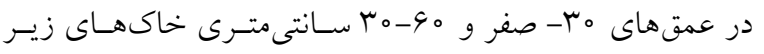

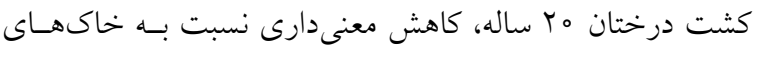

Yo-90 سانتى مترى خاكهاى كشت شده نسبت به خاك كشت نشده نشان داد (Y). ميتال و همكاران با بررسى وضعيت يتاسيم

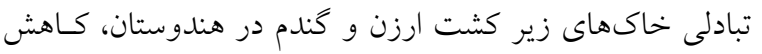

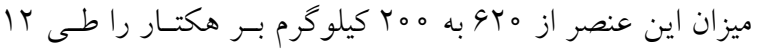
سال كشت فشرده مشاهده كردند (19). جابجى و جكسون در يزوهشى در ايالـت متحــده آمريكـا

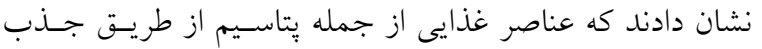

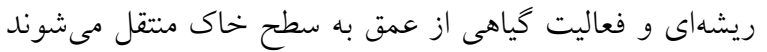

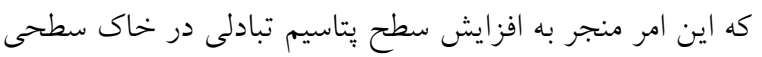

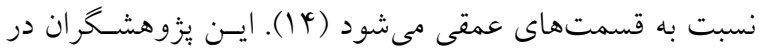

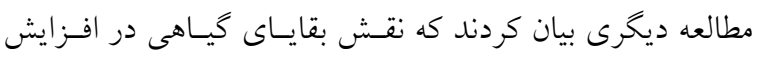

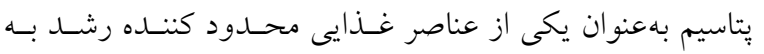
خاك سطحى از اهميت ويزهاى برخوردار است. آنها نشان دادند

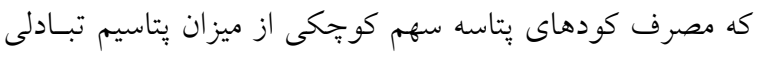

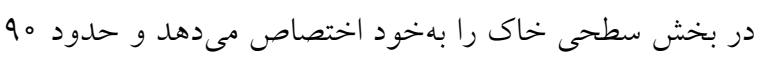

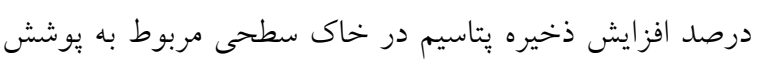

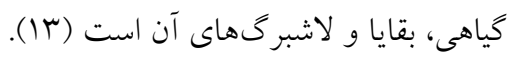

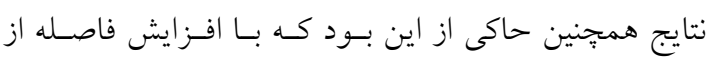

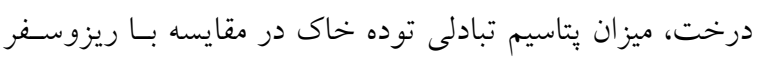

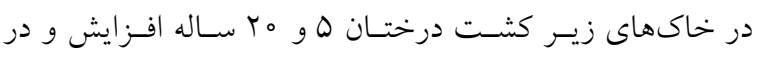

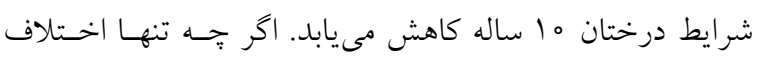




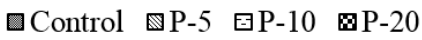

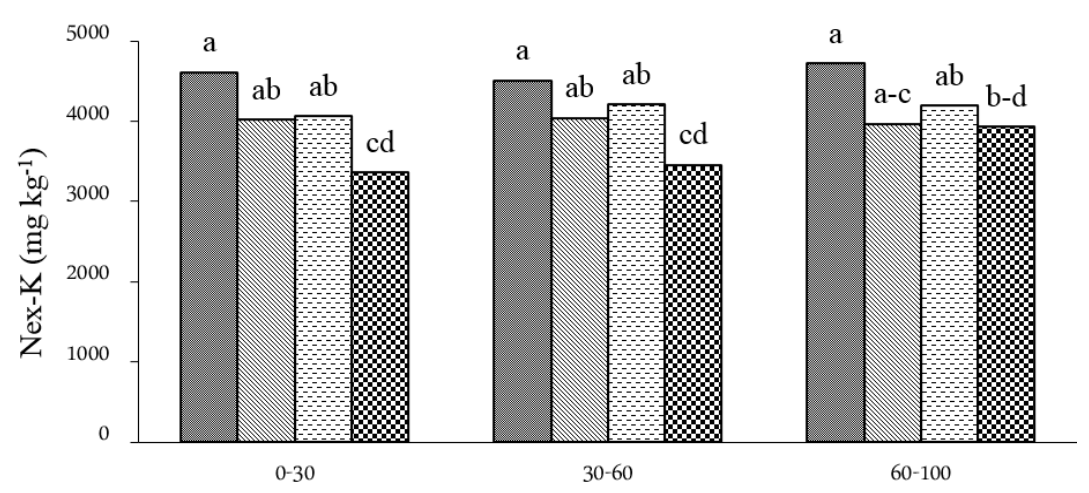

عمق (cm)

شكل ه. اثر سن درختان برتقال بر بتاسيم غيرتبادلى خاك در اعماق مختلف. ميانخينهاى داراى حروف مشترى فاقد تفاوت معنىدار در سطح ينج درصد آمارى هستند.

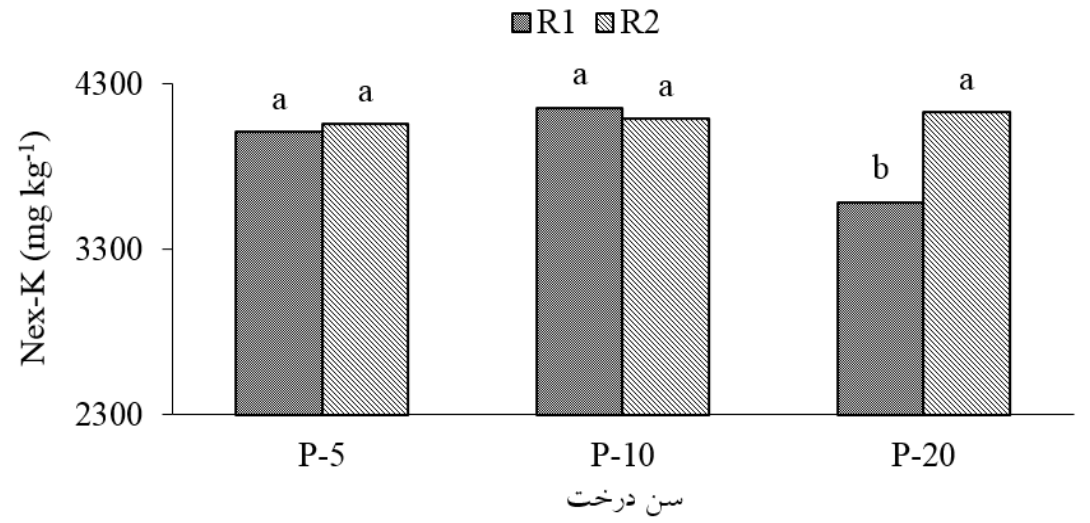

شكل و. اثر فاصله از درخت بر بتاسيم غيرتبادلى خاكهاى زير كشت درختان برتقال با سنين متفاوت. ميانخينهاى داراى حروف مشتر ك فاقد تفاوت معنى دار در سطح ينج درصد آمارى هستند. R1 و R2 بهترتيب ريزوسفر و توده خاك هستند.

غيرتبادلى در نتيجه كشتو كار نبودند (10). بررسـى ميـزان يتاسـيم غيرتبــادلى در ريزوسـفر و تــوده خاكهاى زير كشت درختان برتقال نشان داد كه تنهـا اخـتلاف معنى دار آمارى در سطح ينج درصد مربسوط بـه خاكهـاى زيسر كشت درختان م. ساله است و تـوده خــاك از مقـدار بيشـترى يتاسيم در مقايسه با خاك ريزوسفر برخوردار است (شـكل 9). علت كاهش يتاسيم در ريزوسفر را مىتوان به فعاليت، ترشحات و ميزان بيشتر ريشـههـاى مـويين و در نتيجـهـ مصـرف يتاسـيم كانى هاى خاى در اين فاصله نسبت داد.
كشت نشده و خاكهاى زير كشت درختان ساير سنين در سطح ينج درصد دارد ولى خاكهاى زير كشت درختان ه و ه ا سـاله

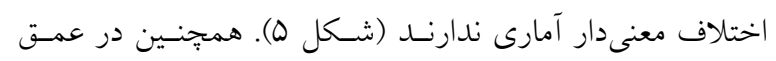
ro مo-100 ساله كاهش معنى دار نسبت به خاى كشت نشده نشان مىدهد. نتايج مشابهى از كاهش يتاسيم غيرتبادلى در باغهاى يسته با كروههـاى سـنى متفــاوت در رفسـنجان توسـط حسـينى فـرد و

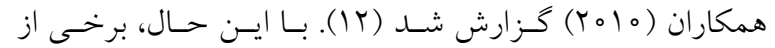
مطالعات قادر به نشان دادن هيج گونه كاهشى در غلظت يتاسـيم 


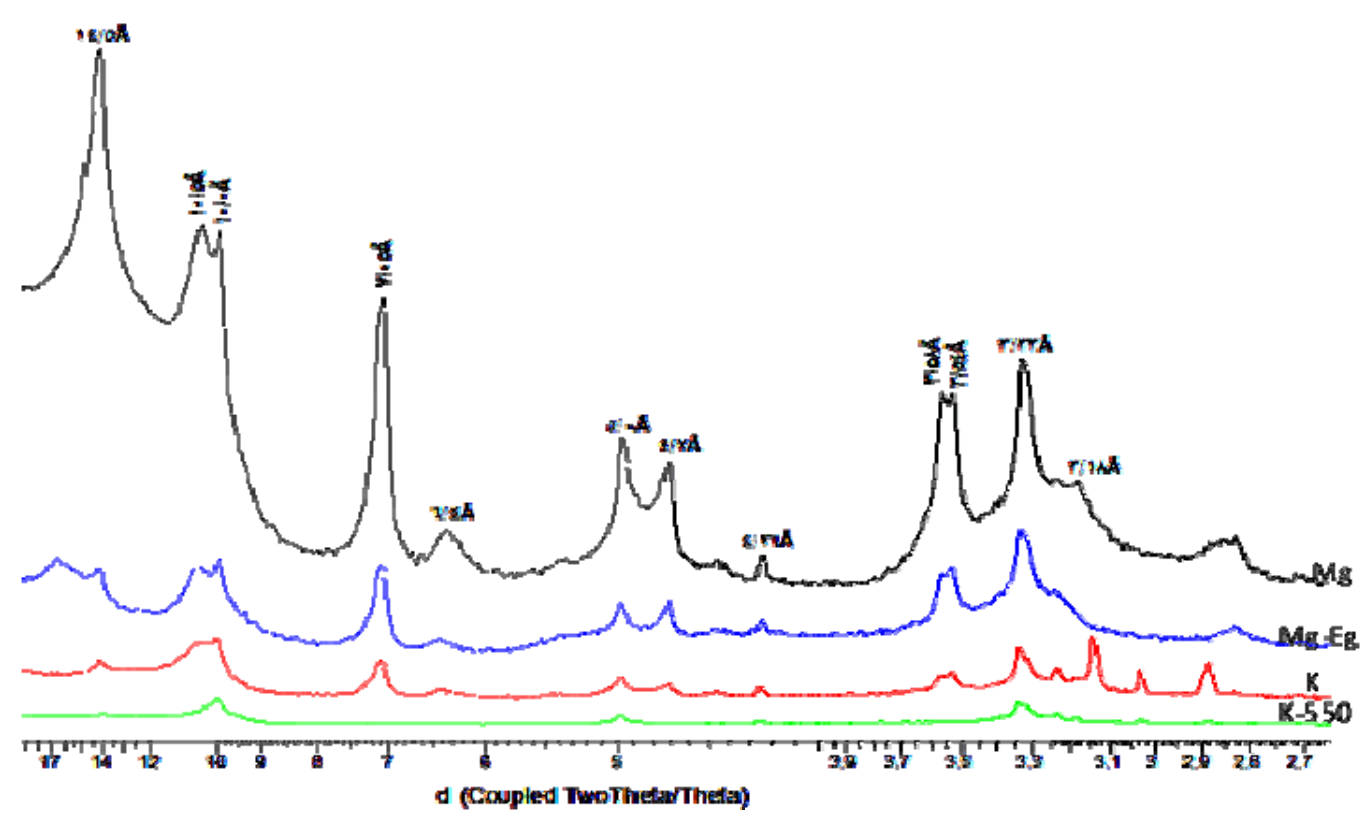

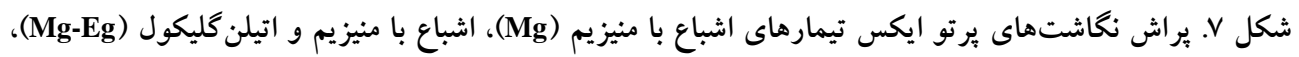

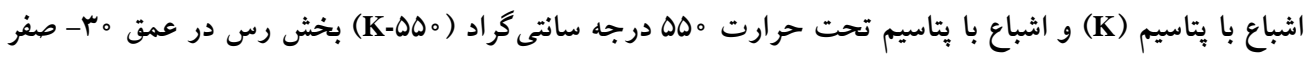
سانتىترى خاك ريزوسفرى درخت برتقال ينج ساله

آنخستروم مربوط به كانى هاى ميكايى يا ايليت، رابطه مستقيم و

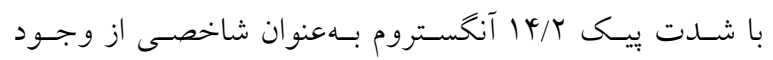

$$
\text { كانى هاى كروه اسمكتيت، رابطه عكس دارد. }
$$

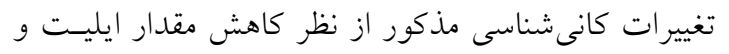

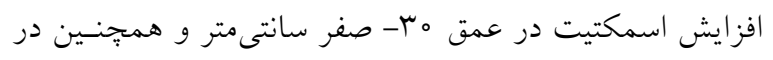

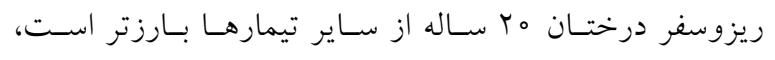

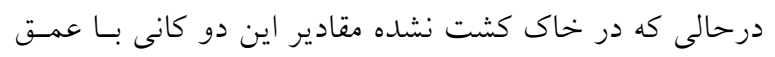

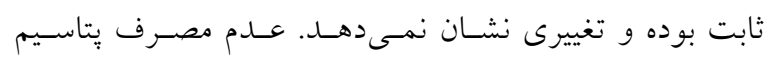

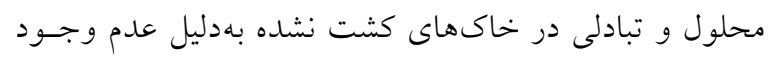

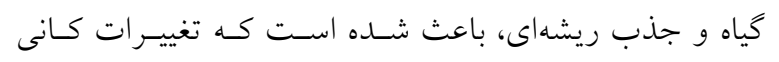
شناسى در اين خاك نسبت به خاكهاى ديخر مشاهده نشـود.

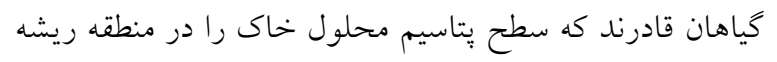

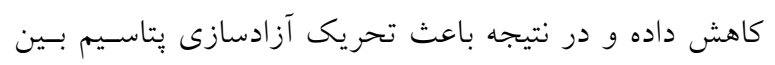

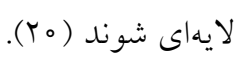

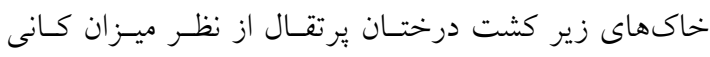
ايليت همخى نسبت به خاكهاى كشت نشده كاهش و و از لحاظ
كانىهاى رسى خاك و تغييرات آنها در خاكهاى زير كشت برتقال با سنين مختلف

منحنىهاى يرتو ايكس ذرات رس خاكهاى مورد مطالعه نشان

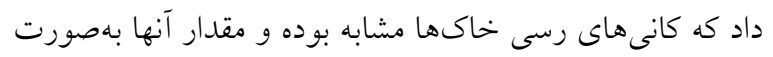

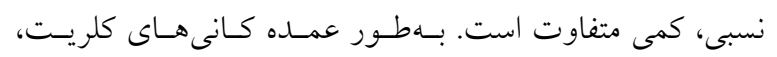

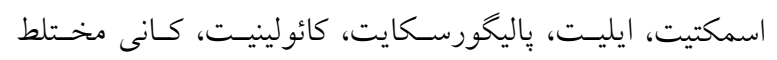

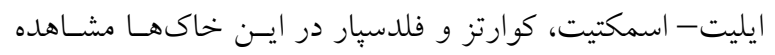

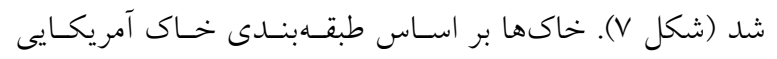

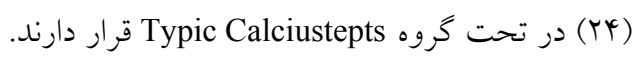
آناليز نيمه كمّى كانى هاى رسى نشان دان داد كه كمتـرين ميـزان

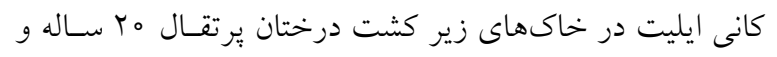
بيشترين مقدار نيز در خاك كشت نشده وجود دارد (شـكل م).

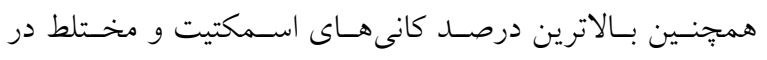

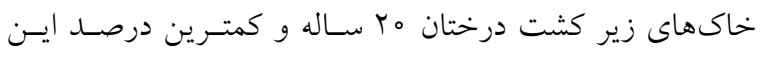

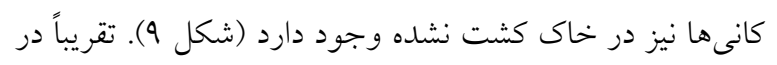

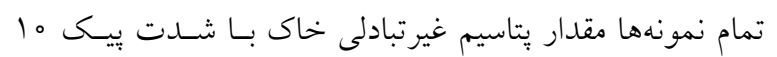




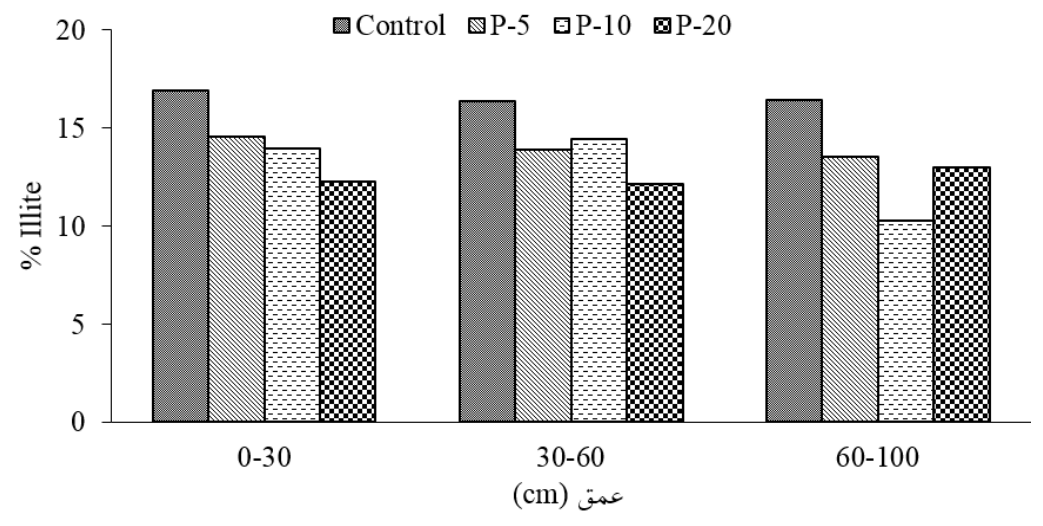

شكل ^ـ مقايسه مقادير كانى ايليت در عمقهاى مختلف خاكهاى زير كثت يرتقال با سنين مختلف

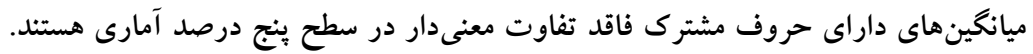

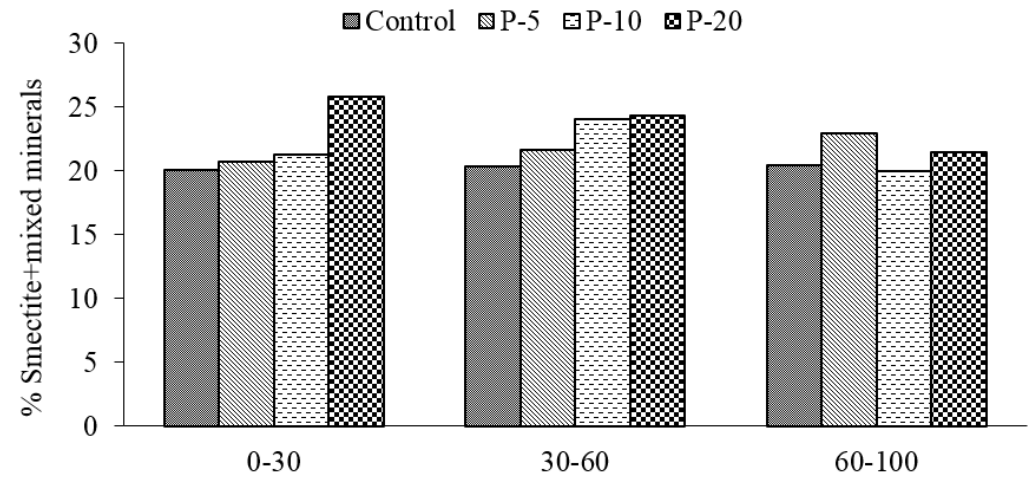

عمق (cm)

شكل 9. مقايسه مقادير كانىهاى اسمكتيت و مختلط در عمقهاى مختلف خاكهاى زير كثت برتقال با سنين مختلف

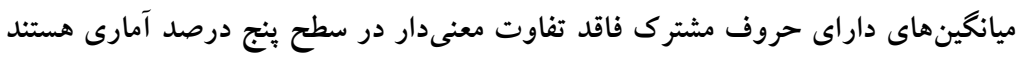

مقدار كانىهاى مختلط و اسمكتيت افزايش نشان مىدهند. دليل خاك شديدتر بوده است.

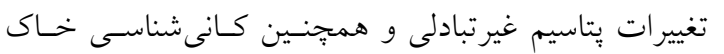

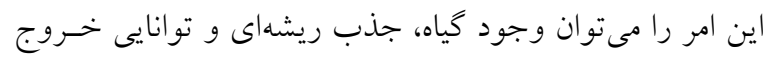

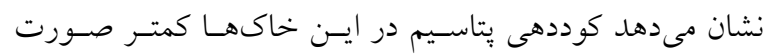
يتاسيم غيرتبادلى از فضاى بين لايهاى كانى هاى بيوتيت يا ايلى ايليت

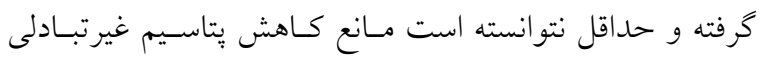

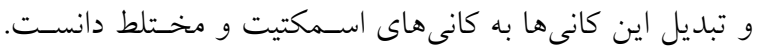

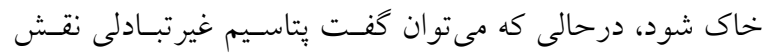
ارزيابى مقادير كانىهـاى رسى و يتاسـيم غيرتبـادلى در ســين

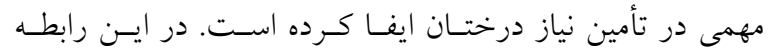

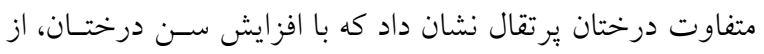

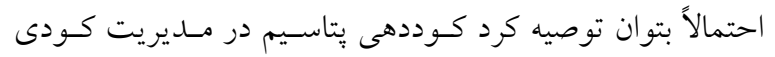

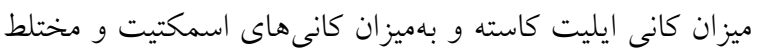
مورد توجه قرار كيرد. حسينى فرد با بررسى كـانىشناسى رسى و ويز كـىهـاى

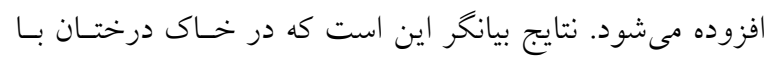

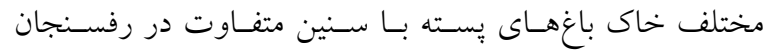

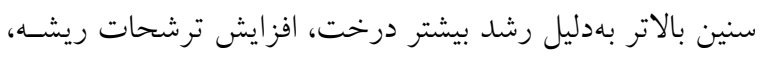

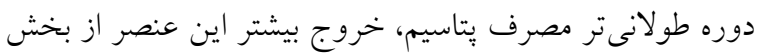

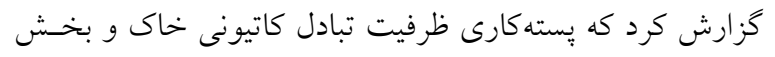

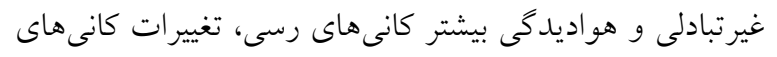


يتاسيم تبادلى نسبت به فاصله از درخت مشابه تغييرات يتاسـيم

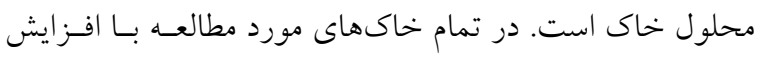
عمق از ميزان يتاسيم محلول و تبادلى كاسته مى شود در صورتى كه يتاسيم غيرتبادلى در خاكهاى زير كشت درختان ينج ساله با

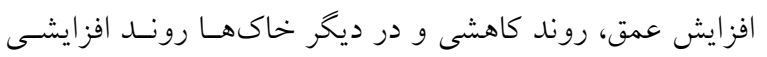
نشان مىدهد. بهنظر مىرسد كه كاربرد كود و باز خشـت بقايـا و لاشبرى درختان به سطح خاى سبب افزايش شكل هاى محلول و تبادلى در سطح شده و همجنين جذب ريشهاى در عمقهـاى بيشتر منجر به كاهش اين شـكل هاى يتاسـيم بـا افـزايش عمـق

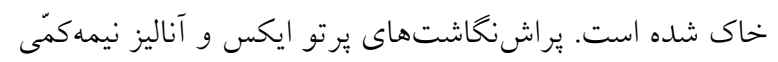
كانى هاى رسسى نشـان داد كـه بيشـترين ميـزان كـانى ايليـت و كمترين مقدار كانىهاى اسمكتيت و مختلط ايليـت- اسـمكتيت متعلق به خاكهاى كشت نشده و كمترين درصد كانى ايليـت و بيشترين درصد كانى هـاى اسـمكتيت و مخـتلط نيـز متعلـق بـه خاكهاى زير كشت درختان برتقال هب ساله است. بـا افـزايش سن درختان و كسترش سيستم ريشهاى و جذب بيشـتر يتاسـيم خاك، از ميزان كانى ايليت و در نتيجه يتاسيم غيرتبـادلى خـاك كاسته و بهميزان كانى هاى اسمكتيت و مختلط افزوده مسىشـود. لذا بر اساس نتايج بهدست آمده، بهمنظور جلـو گيرى از كـاهش بيش از حد ذخيره يتاسـيم در خاكهـاى زيــر كشـت درختـان يرتقال بهويزه در باغهاى با سنين بيشـتر، بـر كـوددهى بيتاسـيم

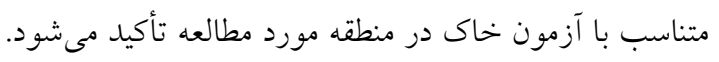

رس را افزايش داده است كه اين افزايش با تغييرات كانىشناسى

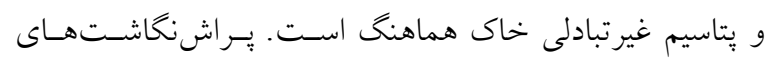
يرتو ايكس بخش رس افقهاى مختلف در درختان يسته با سن

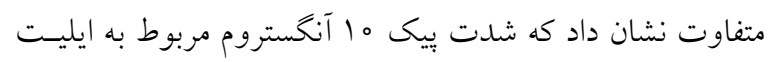

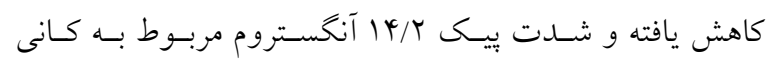
اسمكتيت در مقادير متفاوت افزايش داشته است (11). كومرس

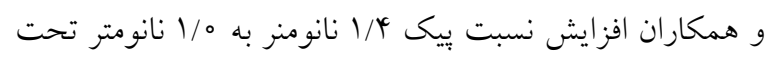

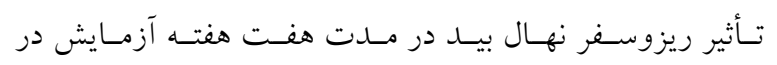
غلظتهاى يايين پِتاسيم محلول را به تشكيل كانى ورميكوليـت

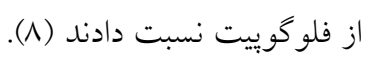

\section{ثتيجه كيرى}

نتايج نشان داد كه ميانخين بِتاسيم محلـول و تبـادلى خاكهـاى زير كشت درختان برتقال كمتر از خاكهاى كشت نشده اسـت. ميزان يتاسيم غيرتبادلى در خاكهاى زير كشت درختان ه ب ساله نسبت به درختان ديخر و خاكهاى كشت نشـده كـاهش نشـان مىدهد كه احتمـالاً فعاليـت ريشـهاى در طـى مب سـال باعـث هواديـدكى، تجزيسه كانىهـاى بتاسـيمدار و در نتيجـهـ مصـرف بتاسيم كانى هاى خاى شـده اسـت. غلظـت بتاسـيم محلـول و تبادلى موجود در ريزوسفر و توده خاك در درختـان يـنج سـاله

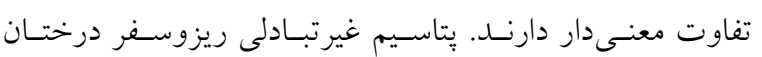

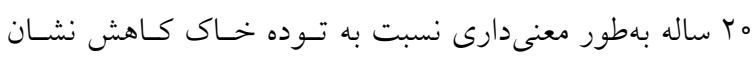
مىدهد. نتايج هم:جنين حاكى از اين است كه الخـوى تغييـرات

\section{منابع مورد استفاده}

1. Bakker, M. R., A. Dieffenbach and J. Ranger. 1999. Soil solution chemistry in the rhizosphere of roots of sessile oak (Quercus petraea) as influenced by lime. Plant and Soil 209: 209-216.

2. Barani Motlagh, M. and G. Sevaghebi. 2005. Study of soil K depletion under sugarcane cropping in Khuzestan. Iranian Journal of Agricultural Science 36(5):1185-1196 (In Farsi).

3. Burt, R. 1992. Soil Survey Laboratory Methods Manual. USDA, Washington.

4. Calvaruso, C., C. Collignon, A. Kies and M. Turpault. 2014. Seasonal evolution of the rhizosphere effect on major and trace elements in soil solutions of Norway spruce (Picea abies Karst) and beech (Fagus sylvatica) in an acidic forest soil. Open Journal of Soil Science 4: 323-336.

5. Dieffenbach, A., A. Göttlein and E. Matzner. 1997. In-situ soil solution chemistry in an acid forest soil as influenced by growing roots of Norway spruce (Picea abies [L.] Karst.). Plant and Soil 192: 57-61.

6. Dieffenbach, A. and E. Matzner. 2000. In-situ soil solution chemistry in the rhizosphere of mature Norway spruce (Picea abies [L.] Karst.) trees. Plant and Soil 222: 149-161. 
7. Fotouhi Ghazvini, R. 2006. Citrus culture in Iran. Guilan University Press, Iran. (In Farsi).

8. Gommers, A., Y. Thiry and B. Delvaux. 2005. Rhizospheric mobilization and plant uptake of radiocesium from weathered micas: I. Influence of potassium depletion. Journal of Environmental Quality 34: 2167-2173.

9. Harris, W. and G. N.White. 2008. X-ray diffraction techniques for soil mineral identification. Methods of Soil Analysis 5: 81-115.

10. Hebsur, N. and T. Satyanarayana. 2002. Potassium status and clay mineralogical composition of some sugarcane soils of North Karnataka. In: Proceeding of the $17^{\text {th }}$ World Congress of Soil Science. Bangkok, Thailand.

11. Hosseinifard, S. J. 2010. Mineralogical and chemical transformations of selected K-bearing minerals in pistachio and wheat root zone. PhD. Thesis, Isfahan University of Technology, Isfahan (In Farsi).

12. Hosseinifard, S. J., H. Khademi and M. Kalbasi. 2010. Different forms of soil potassium as affected by the age of pistachio (Pistacia vera L.) trees in Rafsanjan, Iran. Geoderma 155: 289-297.

13. Jobbágy, E. G. and R. B. Jackson. 2001. The distribution of soil nutrients with depth: Global patterns and the imprint of plants. Biogeochemistry 53: 51-77.

14. Jobbágy, E. G. and R. B. Jackson. 2004. The uplift of soil nutrients by plants: biogeochemical consequences across scales. Ecology 85: 2380-2389.

15. Khayamim, F., H. Khademi and M. R. Sabzalian. 2009. The ability of two types of Geramineae to take up potassium from phlogopite. In: Proceeding of the $11^{\text {th }}$ Soil Science Congress of Iran. Gorgan University of Agricultural Sciences and Natural Resources, Iran. (In Farsi).

16. Knudsen, D., G. A. Peterson and P. F. Pratt. 1982. Lithium, sodium and potassium. PP: 225-246. In: A. L. Page (Ed.), Methods of Soil Analysis. Part 2 .Chemical and Microbiological Properties. Madison, WI: American Society of Agronomy, Soil Science Society of America.

17. Markewitz, D. and D. D. Richter .2000. Long-term soil potassium availability from a Kanhapludult to an aggrading loblolly pine ecosystem. Forest Ecology and Management 130: 109-129.

18. Mirza, M. and Z. Baher Nik. 2006. The Role of deterpination on the essential oil composition of Citrus sinensis (L.) osbeck. Iranian Journal of Medicinal and Aromatic Plants 22: 250-255 (In Farsi).

19. Mittal, S. B., R. Singh, S. C. Mehta and M. Singh. 1990. Potassium depletion under long-term fertilization in a semi-arid soil in India. The Journal of Agricultural Science 115: 173-178.

20. Mutscher, H. 1995. Measurement and Assessment of Soil Potassium. International Potash Institute, Basel (Switzerland), IPI Research Topics.

21. Norouzi, S. and H. Khademi. 2007. Vermiculitization of selected micaceous minerals as influenced by the alfalfa rhizosphere. In: Proceeding of the $15^{\text {th }}$ Symposium of Crystallography and Mineralogy of Iran. Ferdowsi University of Mashhad, Iran. (In Farsi).

22. Shady, M., I. Ibrahim and A. Afify. 1984. Mobilization of elements and their effects on certain plant growth characteristics as influenced by some silicate bacteria. Egyptian Journal of Botany 27: 17-30.

23. Snapp, S., R. Koide and J .Lynch. 1995. Exploitation of localized phosphorus-patches by common bean roots. Plant and Soil 177: 211-218.

24. Soil Survey Staff. 2014. Keys to Soil Taxonomy. $12^{\text {th }}$ ed. USDA-Natural Resources Conservation Service, Washington, DC.

25. Sparks, D. L. 2000. Bioavailability of soil potassium. PP: D38-D53. In: M. E. Sumner (Ed.), Handbook of Soil Science. CRC Press. Boca Raton. FL.

26. Swarup, A. and R. K. Chhillar. 1986. Build up and depletion of soil phosphorus and potassium and their uptake by rice and wheat in a long-term field experiment. Plant and Soil 91: 161-170.

27. Trehan, S. P., H. El Dessougi and N. Classen. 2005. Potassium efficiency of 10 potato cultivars as related to their capability to use nonexchangeable soil potassium by chemical mobilization. Communications in Soil Science and Plant Analysis 36: 1809-1822.

28. USDA-NRCS. 1996. Soil Survey Laboratory Methods Manual. Soil Survey Investigations Report (SSIR), USDA, Lincoln, Nebraska.

29. Wang, J. G., F. S. Zhang, Y. P. Cao and X. L. Zhang. 2000. Effect of plant types on release of mineral potassium from gneiss. Nutrient Cycling in Agroecosystems 56: 37-44.

30. Zeng, D. Q., P. H. Brown and B. A. Holtz. 1999. Effects of potassium fertilization on soil potassium distribution and balance in pistachio orchards. Better Crops 83: 24-26. 


\title{
Changes in Different Forms of Potassium and Clay Minerals in Soils as Influenced by Different Aged Orange Trees (Citrus sinensis) in Darab, Fars Province
}

\author{
V. Shahrokh, H. Khademi* and H. Shariatmadari ${ }^{1}$
}

(Received: May 6-2017 ; Accepted: January 30-2018)

\begin{abstract}
Despite the great importance of potassium applied as a fertilizer in the orange orchards, no information is currently available regarding the rate of potassium release from rhizosphere and the bulk soils of such trees. The objectives of this study were to investigate the weathering of micaceous minerals and their non-exchangeable $\mathrm{K}$ release and also, to examine the status of different forms of $\mathrm{K}$ in the rhizosphere and bulk soils of orange orchards with different ages in Darab, Fars Province. Samples were, accordingly, taken from the rhizosphere and bulk soils of orange orchards with the ages of 5, 10 and 20 years; also, virgin soils (control) were obtained from three soil depths including 0-30, 30-60, and 60-100 cm. Water soluble, exchangeable and nonexchangeable $\mathrm{K}$, and the clay mineralogy of the soils were determined. The results demonstrated that the concentration of soluble and exchangeable $\mathrm{K}$ in the cultivated soils was less than that in the control soil and that the concentration of nonexchangeable $\mathrm{K}$ in the soils of 20-year-old orchards was less, than that in other soils. Soluble and exchangeable K values decreased with depth in all soils. Clay mineralogy investigation also showed that the quantity of illite decreased and that of smectite and illite-smectite increased as the age of orange trees was raised. With increasing the age of orange trees and root development, more potassium could be taken up from soil and more changes occurred in the soil minerals. In order to avoid a very high decline in the reserved $\mathrm{K}$ in the soils under orange trees, particularly in the orchards with older trees, $\mathrm{K}$ fertilization has to be taken more seriously based on the soil testing results.
\end{abstract}

Keywords: Potassium, Rhizosphere, Clay minerals, Orange orchard (Citrus Sinensis)

1. Department of Soil Science, College of Agriculture, Isfahan University of Technology, Isfahan, Iran.

*: Corresponding Author, Email: hkhademi@cc.iut.ac.ir 